\title{
SDS AND THE "IRON LAW OF OLIGARCHY"
}

\author{
Dale Stone \\ Westmar College
}

\begin{abstract}
During the decade 1960-1970 the student movement increased in intensity and influence. A vanguard organization of the movement was Students for a Democratic Society. From an obscure beginning, this splinter group from the League for Industrial Democracy advanced to lead the student movement during some of the most active years. By the end of the decade however, SDS had crumbled and had itself split into several splinter organizations. Through an historical analysis one can see the oligarchical trend which SDS took during the latter part of the decade, a trend which resulted in the nearly total demise of the organization. One possible reason for this demise resulted from the student movement leadership role which SDS held, and the effects of this position on the internal functioning of the organization.
\end{abstract}

This paper is an attempt to evaluate the organization, Students for a Democratic Society (SDS), in accordance with the principles involved in (1) the secondary relationships which Alexis de Tocqueville saw as necessary for a democracy, and (2) Robert Michels' "iron law of oligarchy."

Michels, in his book, Political Parties, presents the "iron law of oligarchy." This "iron law" resulted from his study of political parties, especially the German Social Democratic Party (Lipset, et al., 1962:4). In Michels' own words, the "iron law of oligarchy" is "organization which gives birth to the dominion of the elected over the electors, of the mandataries over the mandators of the delegates over the delegators. Who says organization, says oligarchy" (1959:401). This conclusion stems from Michels' belief that "The nature and requirements of large-scale organizations are such as to give to the men who control the organizational machinery at any given time a near monopoly over all the resources through which power is gained and exercised in private organizations" (Lipset, et al., 1962:464).

In 1956, Lipset, Trow and Coleman, in Union Democracy, published the results of their research in the International Typographical Union (ITU). The ITU was the most notable exception in the American union system to Michels' concept of the "iron law." With a two-party system for union leadership, the ITU functioned well as a democracy. One of the main factors in the success of democracy in the ITU was the secondary associations which Tocqueville had earlier envisioned as necessary for the existence of a democracy (1962:117). Lipset, Trow and Coleman distinguish between the types of secondary associations and that which would lead to a democracy.

A. Nonexistence of secondary organizations, or a mass society, helps maintain a conservative oligarchy, such as is found in South American dictatorships, in Europe before the nineteenth century, or in the average stable American trade union. 
B. Existence of secondary organizations

1. controlled by the government helps maintain revolutionary totalitarianism, intent on making changes within the society which it governs, as in Nazi Germany or Soviet Russia.

2. independent of the government helps maintain democracy, such as is found within the ITU or in the United States or most European democracies (1962:89).

Historically, SDS was an off-shoot of the socialist-oriented League for Industrial Democracy, and began late in 1961. Most of the founding members were college 1iberals influenced by the writing of $\mathrm{C}$. Wright Mills and Michels himself, making them aware of the "iron 1aw" concept (Newfield, 1966:83-100; Rothstein, 1971:2).

The basic principles of SDS wereput in the founding document, the "Port Huron Statement," drafted by Tom Hayden. T he central principle was "particlpatory democracy" which is presented as:

We seek the establishment of a democracy of individual participation governed by two central aims: that the individual share in those social decisions determining the quality and the direction of his life, that society be organized to encourage independence in men and provide the media for their common participation (Kopkind, 1965:16).

Participatory democracy is an encouragement to downtrodden persons to assert themselves in government decisions which affect their lives. Participatory democracy was practiced at local and national meetings, sometimes with success and sometimes resulting in chaos, disruption or boredom.

This central guiding principle of participatory democracy was tested by three main thrusts of SDS programs during the 1960's. Organization of poor communities, social action in the universities, and community work in the new middle class were the areas.

From 1962-1965 SDS was involved in organizing the poor through projects known as ERAP (Economic Research and Action Projects). Some of the issues attacked were poor housing conditions and high rent, educational policies, police harassment, welfare programs, and simply being "left out" (Kopkind, 1965:16). The degree of success of ERAP projects varied in the different metropolitan areas in which they were located. Also during this period, SDS and SNCC (Student Non-Violent Coordinating Committee) were working together in the area of civil rights (Hope, 1970:268).

In 1965 SDS changed the emphasis of its programs. During this second stage SDS went to the students and the universities. Disillusionment with the gains made by ERAP and non-violent civil rights demonstrations caused SDS to look for another pocket of American society in which an initiation of change could begin. As American involvement in the Vietnam War increased and as sentiment against this involvement increased, SDS began to view the educational centers of society as a source for change. Publicity received from government investigations of SDS, attacks by influential U.S. senators, the rapid growth of new SDS chapters, and the October, 1965 March in Washington quickly boosted SDS to the leadership role in the student movement (Newfield, 1965:330). Direct anti-Vietnam War activities were the focal point in 1965, and this issue was directly involved in subsequent activities of SDS. The draft became a central point of SDS activity in 1966. In 1967 harassment of militaryindustrial recruiters was the target of confrontation tactics which were direct and often militant encounters with the opposition. In 1968 SDS began appealing directly to the university to initiate programs and policies of reform. The students saw the university itself as a catalyst for societal change (Vaughn, 1968:81). 
In spite of a very influential role on the campus, in the late 1960's SDS began to search for new areas of concentration. Their goals of responsible society and of responsible government had not been abandoned, but the university was no longer seen as the main catalyst for this change. The feeling was that national authority would not correct its course until the people became active in making decisions, active in controlling their elected officials. This led to the third and final thrust among the new middle class. This new middle class was the university educated workers involved in human services, science, technology, education, and mass communications (Flacks, 1971:31). The enemy was "corporate liberalism" which sought to justify the burden it possessed and therefore, protect itself from change (Jacobs and Landau, 1966: 33). Until this time SDS had remained basically anti-ideological and anti-intellectual, but now some members felt a need for an ideological development in order to benefit the most people in the struggle for change. When SDS returned to the "new" community, the anti-ideological and anti-intellectual attitudes previously held did not appear as viable. This new middle class needed a common belief in its relation with SDS, and "confrontation tactics" did not appear workable. SDS had not been completely antiideological and anti-intellectual but did not emphasize this aspect for fear of becoming bogged down with analysis and intellectualism, a weakness ascribed to the old Left by the New Left (Blumentha1, 1967:656).

The ethics of SDS were guided by a strict moralism which asked "Is it right to do this?" noi" will it work or who will help?"(Newfield, 1966:93). This ethic led SDS to condemn the Vietnam War because of the murder of innocent people, and that is wrong. This moralist ethic was carried into all areas of work.

The political structure of SDS encountered various transformations as the group attempted to become more democratic and improve the functioning of participatory democracy. From its beginning until 1967, the national convention, attended by al1 members, elected a president, vice-president, and National Executive Committee. The National Executive Committee was to hire a full-time staff. Interim policy decisions between conventions were to be made by the National Council, composed of the National Executive Committee and local chapter representatives. As time progressed the power of the president diminished and that of the National Executive Committee's appointed secretary increased. At the 1967 national convention the offices of president and vice-president were dropped. The National Council was to elect three secretaries to work together in the national office - a National Secretary, an InterOrganizational Secretary, and an Internal-Education Secretary. Also at this time the National Executive Committee was abandoned because of being "hierarchical and elitist," although its role was actually subordinate to that of the National Council. The National Interim Committee replaced the National Executive Committee with an identical structure and function. The National Interim Committee functioned a short time but was soon disposed of for the same reason used against the National Executive Committee "hierarchical and elitist." A "national collective" was now given power, with members appointed by the staff itself. Throughout this period the National Council was continually losing authority and becoming submissive to the national office (Rothstein, 1971: $1-8)$.

Local1y, chapters were set-up with many decision making powers. This exemplified the belief in a decentralized government. Local chapters were to decide policy and projects virtually independent of the national office. As SDS membership rapidly increased, a need for regional councils developed. With this new added bulkiness to the SDS structure, these relatively new regional councils soon gained much power. In some parts of the country, the local chapters became responsible to the regional councils instead of the regional councils being responsible to local chapters (Rothstein 1971). 
As the 1960's came to a close, SDS was experiencing many internal problems. Factionalism was becoming very evident within SDS. The types of tactics to bring about change, the extension of the student movement as against an emphasis on a worker-student alliance, the alliances of campus workers and students, the emphasis to be placed on combating racism, and U.S. imperialism were among the issues of debate between factions. SDS regulars wanted to carry the student movement into high schools and continue to keep the students centrally involved. The main faction in debate was the Maoist-oriented Progressive Labor Party faction. The Progressive Labor Party (PLP) was concerned with worker-student alliances to effect change, and was opposed to an SDS move into high schools. The Weathermen faction was also growing out of differences in tactical positions with SDS regulars. At the 1969 national convention these differences came to a head with the SDS regulars walking out of the convention and supposedly ejecting the PLP group. This led to a PLP and SDS split. Later, SDS regulars split into the Weathermen and Revolutionary Youth Movement II (Blumenthal, 1967:658; "Mao in Chicago," 1969:76; "Striking Back," 1969:79).

The factional split and demise of SDS resulted from the oligarchical tendencies of an organization as prescribed by Michels, and from a lack of secondary relationships needed for a democracy as prescribed by Tocqueville and evident in the International Typographical Union.

In searching for the major factor leasing to a split and oligarchical organization in SDS, one can conclde that this major factor aas the thrust of SDS into the role of student movement leader.

In the pre-1965 days of SDS, when ERAP and SNCC were areas of the organization's concentration, it functioned we11. The local chapter meetings, national conventions, and local ERAP meetings were conducted according to the principles of participatory democracy. This worked well, and elitism and hierarchy were not evident within SDS. The individual was involved in sharing in the decisions determining the quality and direction of his life. SDS was the organization to encourage independence in men and provided the means for their common participation. This, of course, was the goal of SDS and participatory democracy.

But in 1965 as SDS moved from the poor community to the college campus to initiate reform, it "encountered unanticipated events and realities" (Flacks, 1971). Through a series of relatively quick events, SDS was thrust into the role of student movement leader. The various actions, policies, confrontations, and tactics proposed by SDS in this role received much support from the student movement in general. The leaders of SDS took their movement leadership position seriously and worked hard. When SDS was put into the leadership role of the student movement, it took an elite and hierarchical position. This unanticipated event contradicted important SDS ideologies. Participatory democracy also encountered difficulty as the movement leadership role involved SDS in the many and varied causes of the movement. The large number of movement causes and needs diminished some of the dedicated usage of participatory democracy evident in the pre-1965 SDS. The weakening of participatory democracy, as well as SDS's hierarchical position in the student movement were undermining some important foundation stones.

During this same period the internal structures of SDS were encountering difficulties. As the 1960's came to a close, these difficulties increased and in 1969, SDS split into the Progressive Labor Party, Revolutionary Youth Movement II, and the Weathermen. After 1965, differences of opinion arose within SDS as to exactly what segment of society would be most influential in beginning the process of reform. Some members felt the students could play this role best. Others felt students and non-college youth should be involved. The PLP faction held the belief in a workerstudent alliance and felt that the laboring class needed to organize to overthrow traditional society. Also at issue was the degree of militancy to be used. 
The different viewpoints as to the most important segment of society for effecting change and as to the best tactical approach presented SDS leaders with problems. The rolc of student movement leader required an internally unified SDS organization. This was not the case after 1965 as the PLP faction was growing, and the embryo of the Weathermen faction was evident. From the information gathered, it appears as though SDS leaders neglected the ideal of participatory democracy. Although SDS leaders wanted individuals to help in the decision making process, during this period, it seems SDS leaders unwittingly did not wish the internal organs of SDS to be actively involved in this process, especially regarding fundamental viewpoints. Apparently the SDS central government expressed unwillingness to consider differing viewpoints. This opposition to opposition is indicative of an oligarchical organization.

This is shown more precisely during 1969 when the PLP appeared to have a majority of the national convention delegates. The central office, or SDS regulars, in attempting to control the power, staged a walk-out and "expelled" the PLP faction. This total refusal to submit to a stronger opposition reveals a central government in which those in power wish dominion over the electors, mandators and delegators. This, of course, is the central point of Michels' "iron law of oligarchy."

The oligarchical drift of SDS far removed it from the original aspirations. A1though SDS did succeed in furthering the movement and encouraging America to reexamine her conscience, SDS as an organization did fail.

Non-evident within SDS were the secondary associations which Tocqueville had seen as necessary for a democracy and which were evident in the ITU. The PLP and Weathermen did not or were not allowed to exist independent of the SDS central government. Possibly the political personality and purpose of SDS and its members made it impossible for secondary associations to exist apart from the government. SDS existed as a mass society due to this absence of secondary associations. As earlier mentioned, the lack of secondary associations aids in the existence of oligarchies.

A failure by the SDS central government to submit to opposition led to an eventual split of SDS, and finally to the nearly total demise of SDS from its influential position in the New Left. The reason for this movement towards oligarchy may have resulted from a general preoccupation with the student movement as a whole or it may have been for tyrannical motives. I would suggest that the unanticipated elite and hierarchical position of the organization as student movement leader was the central reason, with the actual turn to oligarchy probably unintentional. Whatever the reason, this oligarchical trend resulted in the weakening of participatory democracy. As a result of the unforeseen student movement leadership role and the weakening of participatory democracy, one can conclude that SDS did fall victim to the "iron law of oligarchy."

\section{References}

Blumentha1, Richard

1967 "SDS: Protest is not enough." Nation 204 (May 22):656-660.

Flacks, Richard

1971 "The New Left and American politics after ten years." Journal of Social Issues 27 (no. 1):21-34.

Hope, Majorie

1970 Youth Against the World. Boston: Little, Brown, and Co. 
Jacobs, Paul and Saul Landau

1966 The New Radicals: A Report with Documents. New York: Vintage Books.

Kopkind, Andrew

1965 "Of, by and for the poor." New Republic 152 (June 19):15-19.

Lipset, Seymour, Martin Trow and James Coleman

1962 Union Democracy. New York: Anchor Books.

1969 "Mao in Chicago." Newsweek 73 (June 30):76.

Michels, Robert

1959 Political Parties. Eden and Cedar Paul (trans.). New York: Dover Publications, Inc. (First published in Germany in 1911)

Nachman, Larry David

1969 "Obituary for SDS." Nation 209 (November 24):558-561.

Newfield, Jack

1965 "The student left: Idealism and action." Nation 201 (November 8):330-333.

1966 A Prophetic Minority. New York: New American Library.

Rothstein, Rich

1969 "Striking back." Newsweek 74 (July 7):79.

1971 "Representative democracy in SDS." Chicago: New University Conference.

Vaughn, Roger

1968 "The defiant voices of SDS." Life 65 (October 18):80-96. 